\title{
Kinetic Study of Cd(II) Ions Extraction Using Trioctylamine as Carrier in Bulk Liquid Membrane (BLM)
}

\author{
Meor Muhammad Hafiz Shah Buddin, ${ }^{1 *}$ Nur Athirah Azrai, ${ }^{2}$ Effi Aidur Roza Roseli, ${ }^{2}$ \\ Farhana Wahet ${ }^{2}$ and Abdul Latif Ahmad ${ }^{3}$ \\ ${ }^{1}$ Faculty of Chemical Engineering, Universiti Teknologi MARA, \\ 40450 Shah Alam, Selangor, Malaysia \\ ${ }^{2}$ Faculty of Chemical Engineering, Universiti Teknologi MARA Johor, \\ Kampus Pasir Gudang, Bandar Seri Alam, 81750 Masai, Johor, Malaysia \\ ${ }^{3}$ School of Chemical Engineering, Universiti Sains Malaysia, Engineering Campus, \\ 14300 Nibong Tebal, Pulau Pinang, Malaysia
}

${ }^{*}$ Corresponding author: meorhafiz7767@uitm.edu.my

Published online: 25 August 2019

To cite this article: Shah Buddin, M. M. H. et al. (2019). Kinetic study of Cd(II) ions extraction using trioctylamine as carrier in bulk liquid membrane (BLM). J. Phys. Sci., 30(2), 157-168, https://doi.org/10.21315/jps2019.30.2.9

To link to this article: https://doi.org/10.21315/jps2019.30.2.9

\begin{abstract}
Simultaneous extraction and stripping of Cd(II) ions from aqueous solution by using bulk liquid membrane (BLM) was explored. This study was aimed to identify the conditions to achieve maximum $C d(I I)$ ions removal and the reaction kinetics was thoroughly analysed. The membrane phase was made by using trioctylamine (TOA) and kerosene, as carrier and diluent, respectively. Meanwhile, the feed phase contained the targeted solute $\left(\mathrm{CdCl}_{2}\right)$ dissolved in a $\mathrm{pH}$ adjusted solution while ammonia was used as the stripping agent. To achieve maximum Cd(II) ions removal, the effect of carrier concentration, stirring speed as well as extraction time were studied. Experimental data obtained shows that $0.1 \mathrm{wt} \%$ TOA in kerosene, $400 \mathrm{rpm}$ stirring speed and 4 h of extraction time resulted in highest removal of Cd(II) ions. Furthermore, it was identified that the extraction process across BLM prefers acidic condition ( $\mathrm{pH}$ of 1 ). The capability of the system to extract Cd(II) ions from the feed phase was known by using dimensionless reduced concentration, $R_{f}$ where the maximum removal of $C d(I I)$ ions achieved was 0.0193 at the mentioned conditions. The reaction kinetics were investigated to identify the reaction rate constants for extraction reaction $\left(k_{1}\right)$ and stripping reaction $\left(k_{2}\right)$. The value of $k_{1}$ and $k_{2}$ were found to be $0.94 h^{-1}$ and $2.45 h^{-1}$, respectively.
\end{abstract}

Keywords: Bulk liquid membrane, BLM, Cd(II) extraction, kinetics, trioctylamine 


\section{INTRODUCTION}

Cadmium is a soft, bluish white metal that is very malleable with molecular weight of $112.414 \mathrm{~g} \mathrm{~mol}^{-1}$. It can be easily oxidised in air and in acidic condition, it is soluble and forms ions. $\mathrm{Cd}(\mathrm{II})$ ions is the most common pollutant which has welldocumented records on its bad effects to aquatic life and human beings, mainly due to its toxicity and carcinogenic properties. ${ }^{1} \mathrm{Cd}(\mathrm{II})$ is most often used in the manufacturing sectors such as electroplating, hydrometallurgy and dye synthesis. This type of heavy metal tends to accumulate in the environment as it is nonbiodegradable. ${ }^{2}$ As these sectors expand with time, a more effective and reliable method to reduce $\mathrm{Cd}(\mathrm{II})$ ions contamination is needed.

There are many options available in minimising $\mathrm{Cd}(\mathrm{II})$ ions concentration from aqueous solution. Reported techniques are filtration, flocculation, biological processes, solvent extraction, ions exchange and precipitation. ${ }^{3-5}$ However, these techniques have drawbacks as some of them are energy intensive process besides generating secondary and highly toxic sludge. In addition, they are costly as well as unable to gain high removal of the metal ions. Liquid membrane technology was found to be an alternative method to remove metal ions from aqueous solution at lower cost and it uses minimal amount of solvent. In fact, the process consumes lower energy and can be easily operated. ${ }^{6}$

To date, there are three types of liquid membrane configurations namely emulsion, supported and bulk..$^{7-9}$ Each configuration offers significant advantages. For instance, the emulsion type allows high surface area to volume ratio while supported configuration offers better stability of the membrane. ${ }^{7,10}$ On the other hand, bulk liquid membrane (BLM) is the simplest configuration among all. ${ }^{11}$ All types of liquid membrane share the same solute transportation mode as they require the assistance of carrier to extract the targeted solute from the feed phase. ${ }^{12}$ Liquid membrane combines stripping and extraction process in a single operation. In the context of $\mathrm{Cd}$ (II) ions removal via liquid membrane, the transport of $\mathrm{Cd}(\mathrm{II})$ ions from the feed solution could be assisted by TOA, D2EHPA, CYANEX 272 and LIX $984 \mathrm{~N}$ as the carrier. ${ }^{13-16}$ Figure 1 illustrates the mechanism of $\mathrm{Cd}(\mathrm{II})$ ions extraction through BLM containing TOA as carrier and $\mathrm{OH}^{-}$as counter ions. ${ }^{13}$ TOA diffuses from the bulk membrane phase to the feed membrane interface where it reacts with $\mathrm{Cd}(\mathrm{II})$ ions for protons exchange. This process resulted in the formation of carrier-solute complex. The $\mathrm{Cd}(\mathrm{II})$ carrier complex formed diffuses through the membrane to the stripping interface where ions are exchanged for $\mathrm{Cd}(\mathrm{II})$ by reacting with the counter ions. The carrier-solute complex will be broken down, leading to the stripping of $\mathrm{Cd}(\mathrm{II}) \cdot{ }^{17}$ Following this is the carrier regeneration process that results in a new reaction cycle. The $\mathrm{Cd}(\mathrm{II})$ ions transport mechanism 
is therefore a coupled counter ion transport, with $\mathrm{Cd}(\mathrm{II})$ and $\mathrm{OH}^{-}$ions travelling in the opposite direction. ${ }^{18}$ This mode of transportation is called as Type II Facilitated Transport. ${ }^{17}$

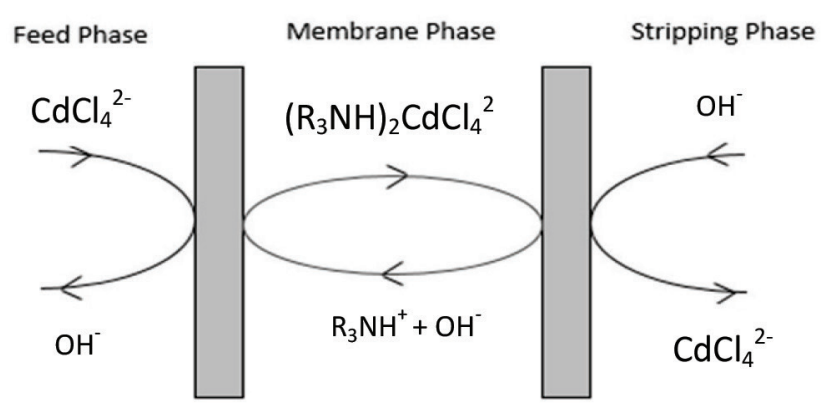

Figure 1: Facilitated counter transport of $\mathrm{Cd}(\mathrm{II})$ ions using TOA as carrier.

Known reactions equations that took place on the interfaces are as follows: ${ }^{13}$

$$
\begin{aligned}
& \mathrm{CdCl}_{4}{ }^{2-}+2 \mathrm{R}_{3} \mathrm{NH}^{+} \leftrightarrow \mathrm{CdCl}_{4}\left(\mathrm{R}_{3} \mathrm{NH}\right)_{2} \\
& \mathrm{CdCl}_{4}\left(\mathrm{R}_{3} \mathrm{NH}\right)_{2}+2 \mathrm{OH}^{-} \leftrightarrow \mathrm{CdCl}_{4}{ }^{2-}+2 \mathrm{R}_{3} \mathrm{~N}+2 \mathrm{H}_{2} \mathrm{O}
\end{aligned}
$$

The objective of this study is to obtain maximum Cd(II) ions removal by looking at the following parameters: carrier concentration, stirring speed and extraction time. The work will be followed by the analysis of kinetics data to determine the reaction rates constants for extraction and stripping reaction.

\subsection{Theory}

From the kinetic data, the reaction rate constant, $\mathrm{k}\left(\mathrm{h}^{-1}\right)$ values will be determined. The kinetic behaviour gives first-order time differentiation that can be described as the equations as following: ${ }^{17}$

$$
\begin{aligned}
\frac{d R_{f}}{d t} & =-k_{1} R_{f} \\
\frac{d R_{m}}{d t} & =k_{1} R_{f}-k_{2} R_{m} \\
\frac{d R_{p}}{d t} & =k_{2} R_{m}
\end{aligned}
$$

Meanwhile, Equations 6, 7 and 8 are the results of integration of Equations 3, 4 and 5, respectively: 


$$
\begin{aligned}
& R_{f}=e^{-k_{1} t} \\
& R_{m}=\frac{k_{1}}{k_{2}-k_{1}}\left[e^{-k^{1} t}-e^{-k_{2} t}\right] \\
& R_{p}=1-\frac{1}{k_{2}-k_{1}}\left[k_{2} e^{-k_{1} t}-k_{1} e^{-k_{2} t}\right]
\end{aligned}
$$

The value of $k_{l}$ is the reaction rate constant for extraction reaction (on feedmembrane interface) and the value of $\mathrm{k}_{2}$ is the rate constant for stripping reaction (on membrane-stripping interface). On the other hand, $R_{f}, R_{m}$ and $R_{p}$ represent dimensionless reduced concentrations of $\mathrm{Cd}$ (II) in the feed, membrane and stripping phase, respectively. They were calculated by taking the ratio of $\mathrm{C}_{\mathrm{ft}}, \mathrm{C}_{\mathrm{mt}}$ and $\mathrm{C}_{\mathrm{pt}}$ to the initial Cd(II) ions concentration in the feed phase. $\mathrm{C}_{\mathrm{ft}}, \mathrm{C}_{\mathrm{mt}}$ and $\mathrm{C}_{\mathrm{pt}}$ are the concentrations of $\mathrm{Cd}(\mathrm{II})$ ions in the feed, membrane and stripping phase at time $t$.

\section{EXPERIMENTAL}

\subsection{Chemicals}

Table 1 provides the list of chemicals used in this study and their purposes. All solutions were prepared by using distilled water and the $\mathrm{pH}$ of the feed phase was adjusted to a desired value before any extraction process took place.

Table 1: Chemicals used and their function in the configuration of BLM.

\begin{tabular}{ll}
\hline Chemicals & Role \\
\hline TOA, supplied by Merck & Carrier \\
Ammonia solution $28 \%\left(\mathrm{NH}_{4} \mathrm{OH}\right)$ & Stripping agent \\
Commercial grade kerosene & Diluent \\
Cadmium chloride $\left(\mathrm{CdCl}_{2}\right)$, supplied by Sigma Aldrich & Solute in feed phase \\
Hydrochloric acid $37 \%(\mathrm{HCl})$ & Feed phase $\mathrm{pH}$ adjustment \\
Sodium hydroxide $(\mathrm{NaOH})$ & \\
\hline
\end{tabular}

\section{$2.2 \quad \mathrm{Cd}(\mathrm{II})$ Ions Extraction Using BLM}

The feed phase was prepared by dissolving $50 \mathrm{ppm}$ of $\mathrm{CdCl}_{2}$ in a $\mathrm{pH}$ adjusted solution. On the other hand, the membrane phase was prepared by dissolving TOA at varying concentrations ( $0.025 \mathrm{wt} \%$ to $0.25 \mathrm{wt} \%)$ in kerosene. As for the stripping phase, $50 \mathrm{ml}$ of ammonia solution was used as stripping agent at concentration of $1.0 \mathrm{M}$. The system was stirred for $4 \mathrm{~h}$ at room temperature at varying speed; 
$100 \mathrm{rpm}$ to $800 \mathrm{rpm}$. The volume ratio of feed to membrane to stripping phase was kept constant at 2:1:1. The setup is illustrated in Figure 2.

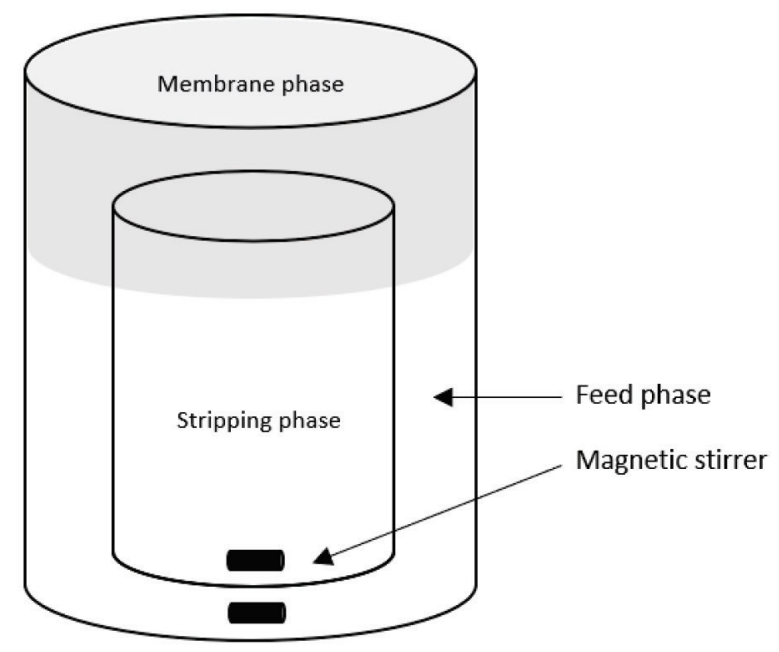

Figure 2. Apparatus setup for BLM.

\subsection{Cd(II) Ions Concentration Measurement}

Once the extraction process ended, the feed and stripping phase solution was taken out to determine the concentration of Cd(II) ions in each phase. Inductive Coupled Plasma Mass Spectrometry, ICP-MS (PerkinElmer) Optima 800J was used to measure $\mathrm{Cd}(\mathrm{II})$ ions concentration in all samples at $228.802 \mu \mathrm{m}$ wavelength. Meanwhile, the concentration of $\mathrm{Cd}$ (II) ions in the membrane phase was calculated by using mass balance. The concentration data obtained was used to calculate the ratio of dimensionless reduced concentration and they were denoted as $R_{f}, R_{m}$ and $\mathrm{R}_{\mathrm{p}}$, referring to ratio in feed, membrane and stripping phase, respectively.

\subsection{Kinetic Study of Cd(II) Ions Extraction and Stripping}

The experiment was carried out at extraction time ranging from $1 \mathrm{~h}$ to $12 \mathrm{~h}$. The speed was kept constant at $400 \mathrm{rpm}$ at initial concentration of $50 \mathrm{ppm}$ of $\mathrm{CdCl}_{2}$ in an acidic solution. $\mathrm{HCl}$ was used to adjust the $\mathrm{pH}$ of the feed to 1 before the extraction process took place. The TOA concentration in membrane phase was kept constant at $0.1 \mathrm{wt} \%$ while the remaining is kerosene. The final concentration of $\mathrm{Cd}(\mathrm{II})$ ions was analysed and the kinetic data was established. 


\section{RESULTS AND DISCUSSION}

\subsection{Effect of External Feed Phase pH}

To determine the effect of $\mathrm{pH}$ in the feed phase on the dimensionless reduced concentration, $\mathrm{R}_{\mathrm{f}}$, the $\mathrm{pH}$ was varied from 1 to 13 . The profile of $\mathrm{R}_{\mathrm{f}}$ against external phase $\mathrm{pH}$ is shown in Figure 3. It can be seen from the figure that the high $\mathrm{pH}$ value ( $>5$ ) causes the $R_{f}$ to increase significantly. The lowest $R_{f}$ with a value of 0.0374 was obtained at a low $\mathrm{pH}$ value which is 1 . This is mainly due to chemical ions speciation, owing to the fact that, the reaction of $\mathrm{Cd}(\mathrm{II})$ ions extraction with the carrier requires the ions to exist in the anionic form $\left(\mathrm{CdCl}_{4}{ }^{2-}\right){ }^{19}$ This ionic species was not formed neither in neutral nor basic medium. This phenomenon limits the capability of the extraction process at higher $\mathrm{pH}$ even though the system was loaded with carrier. As the $\mathrm{pH}$ increases surpassing the neutral, the absence of any $\mathrm{Cd}(\mathrm{II})$ ions species were reported and it is highly likely for $\mathrm{Cd}(\mathrm{II})$ precipitate to be formed.

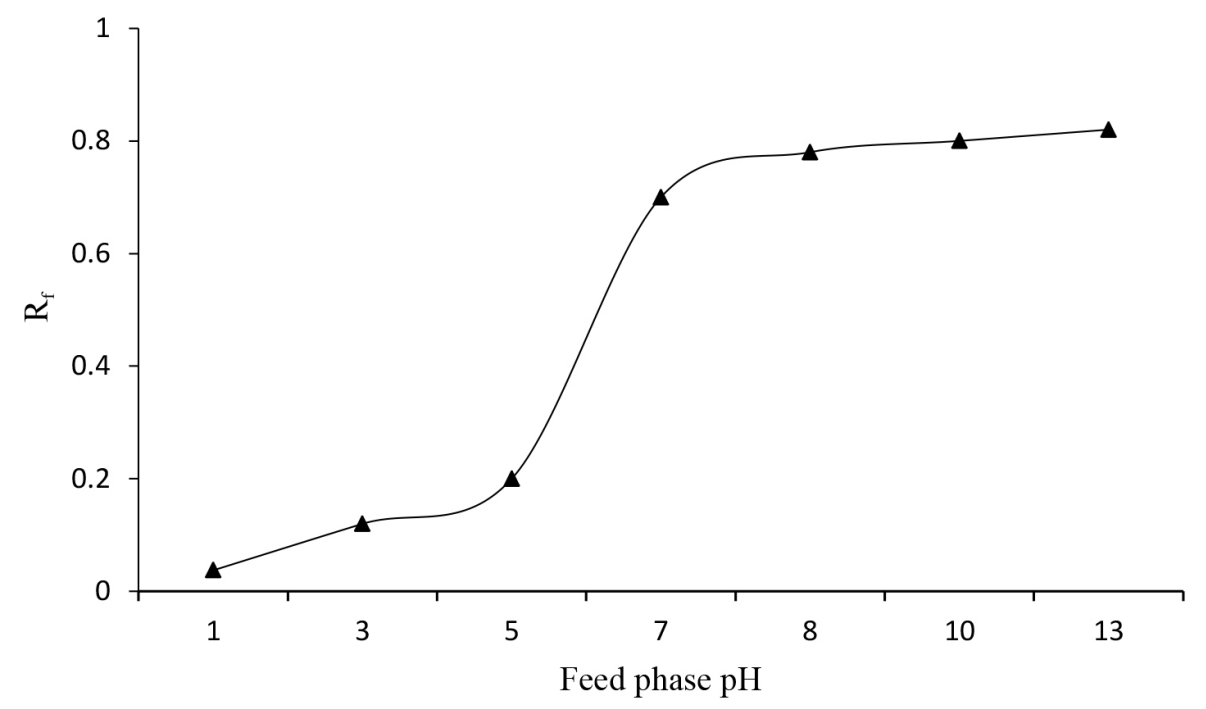

Figure 3: Effect of feed phase $\mathrm{pH}$ on $\mathrm{R}_{\mathrm{f}}$. Experimental conditions are $500 \mathrm{rpm}$ stirring speed, $0.1 \mathrm{wt} \%$ TOA, and $4 \mathrm{~h}$ extraction time.

\subsection{Effect of Carrier Concentration}

Data provided in Figure 4 illustrates the effect of carrier (TOA) concentration on the extraction capability of the system. The data reveals that the transport of Cd(II) ions across the membrane phase were affected by the concentration of TOA. 
From the data provided, increment of TOA concentration from $0.025 \mathrm{wt} \%$ to $0.1 \mathrm{wt} \%$ increases the efficiency significantly. This phenomenon is highly possible to be caused by sufficient amount of carrier existed in the system. Figure 4 shows that further increment of carrier concentration in the membrane over $0.1 \mathrm{wt} \%$ decreases the $\mathrm{Cd}(\mathrm{II})$ removal efficiency.

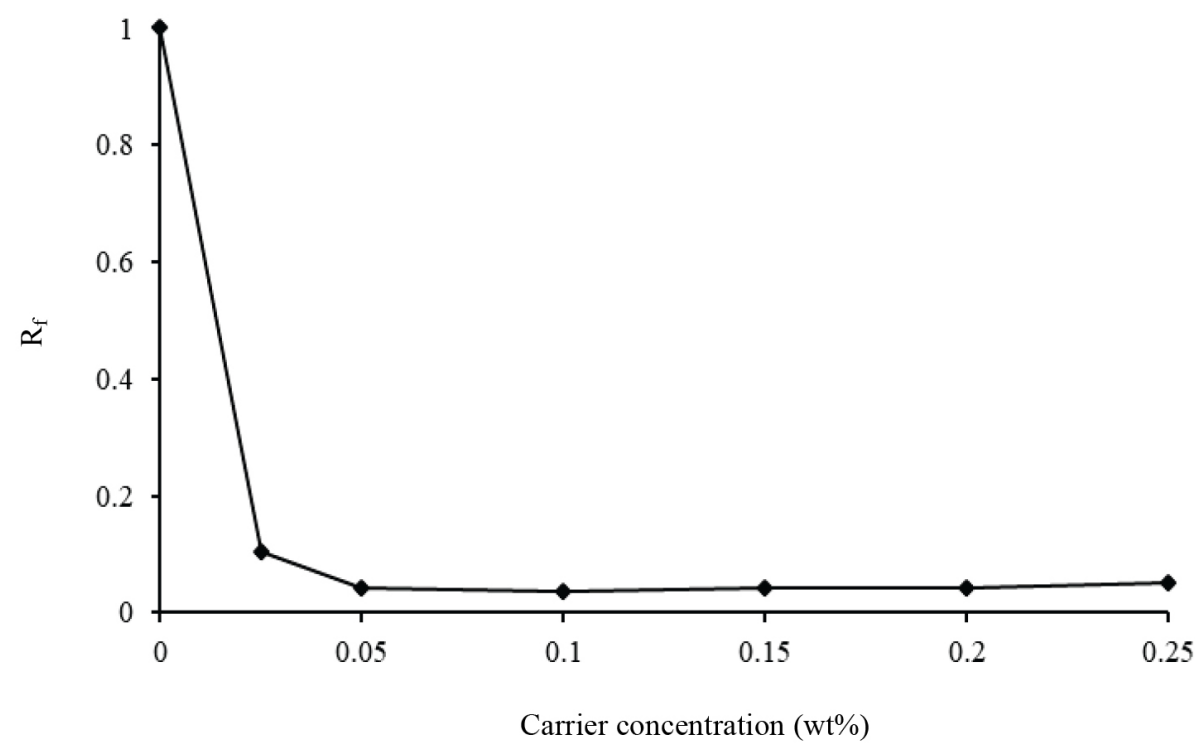

Figure 4: Effect of carrier concentration on $\mathrm{R}_{\mathrm{f}}$. Experimental conditions are $500 \mathrm{rpm}$ stirring speed, $4 \mathrm{~h}$ extraction time, and feed phase $\mathrm{pH}$ of 1.

Low viscosity of the membrane phase at higher carrier concentration eased the stirring process. ${ }^{20}$ This phenomenon resulted in high surface area for extraction process and shorter time is needed for $\mathrm{Cd}(\mathrm{II})$ ions to be transferred into the membrane phase. In fact, shorter path was created for solute diffusion process. Based on Figure 4, any increment of the carrier concentration beyond $0.1 \mathrm{wt} \%$ does not benefit the system significantly. This is due to the fact that, the number of moles of TOA present is said to be sufficient to extract Cd(II) ions in the feed phase. TOA concentration of $0.1 \mathrm{wt} \%$ was selected in this experiment.

\subsection{Effect of Stirring Speed}

Data of dimensionless reduced concentrations, $\mathrm{R}_{\mathrm{f}}$ as a function of stirring speed is presented in Figure 5. The extraction was conducted by using constant TOA concentration $(0.1 \mathrm{wt} \%)$ at different speed of stirring; $100 \mathrm{rpm}$ to $800 \mathrm{rpm}$. As the stirring speed increases, shear provided from the stirrer during stirring reduces 
the membrane globules size, hence providing high interfacial area per volume ratio for extraction process. Increment of $\mathrm{Cd}(\mathrm{II})$ ions extraction is a result of this condition. ${ }^{21}$ It can be explained that faster stirring speed decreased the external mass transfer resistance. ${ }^{22}$ This increment enhanced the external mass transfer coefficient thus more cadmium was extracted into the membrane phase. However, further increment of the stirring speed did not increase the extraction capability significantly. This is highly possible due to the equilibrium achieved and the capacity of the membrane to extract Cd(II) ions has become insignificant due to the concentration gradient. A stirring speed of $400 \mathrm{rpm}$ was selected to extract maximum $\mathrm{Cd}(\mathrm{II})$ ions removal where the $\mathrm{R}_{\mathrm{f}}$ recorded is 0.0193 .

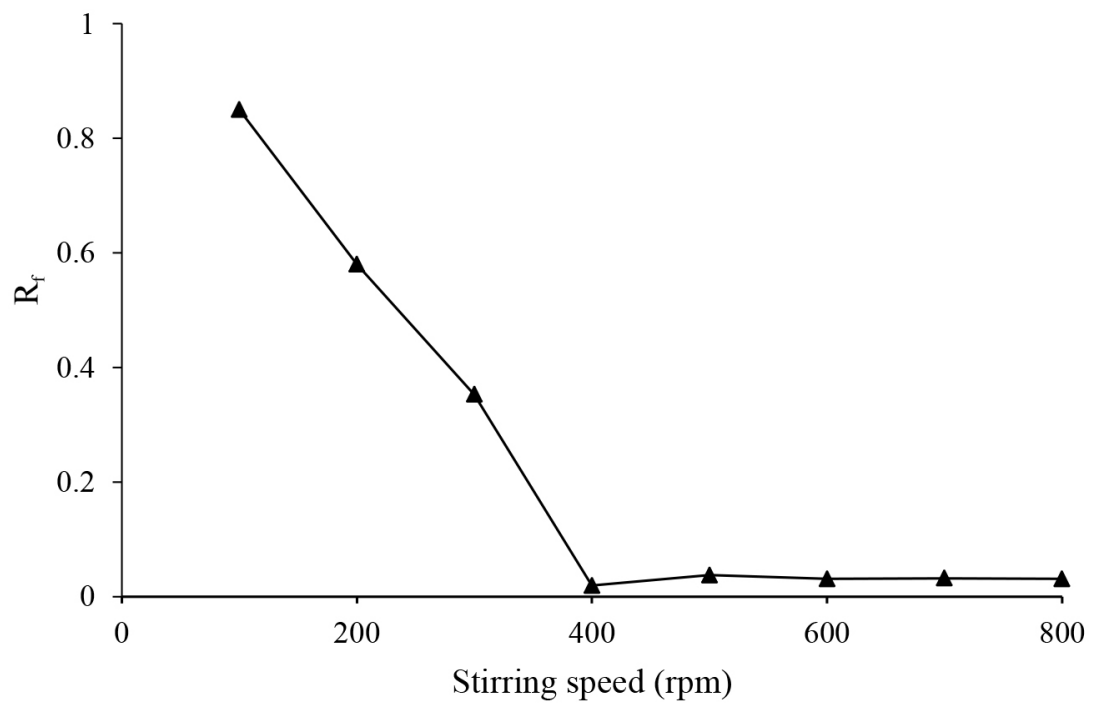

Figure 5: Effect of stirring speed on $\mathrm{R}_{\mathrm{f}}$. Experimental conditions are $0.1 \mathrm{wt} \% \mathrm{TOA}, 4 \mathrm{~h}$ extraction time, and feed phase $\mathrm{pH}$ of 1 .

\subsection{Reaction Kinetics}

Figure 6 shows model curves of $\mathrm{R}_{\mathrm{f}}, \mathrm{R}_{\mathrm{m}}$ and $\mathrm{R}_{\mathrm{p}}$ for $\mathrm{Cd}(\mathrm{II})$ extraction as the reaction progress. The data plotted was calculated from Equations 6, 7 and $8 . \mathrm{R}_{\mathrm{f}}$ was found to decrease monoexponentially, while $\mathrm{R}_{\mathrm{p}}$ follows an increasing sigmoidal type curve and $\mathrm{R}_{\mathrm{m}}$ presented bell-shaped curve. ${ }^{18}$ The concentration of $\mathrm{Cd}(\mathrm{II})$ ions in feed phase decreases as function of time while its concentration in the stripping phase showed the opposite trend. The data obtained proves that $\mathrm{Cd}(\mathrm{II})$ ions was extracted from feed and was stripped in the stripping phase. 


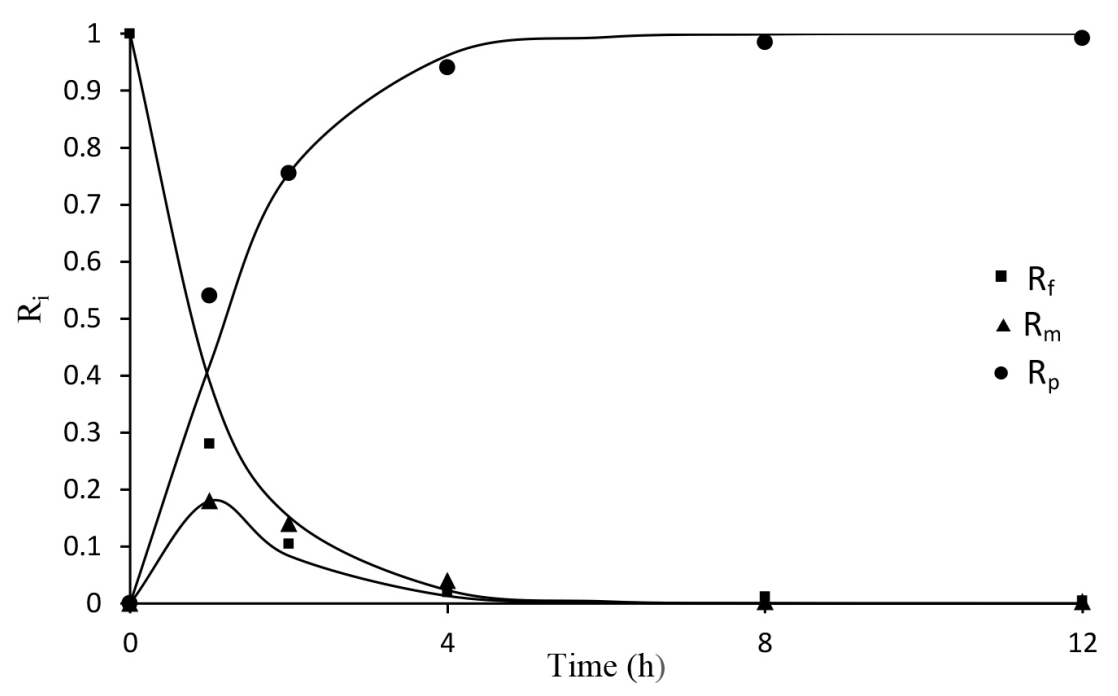

Figure 6: Effect of time on Cd(II) removal efficiency. Experimental conditions are $0.1 \mathrm{wt} \%$ TOA, 4 h extraction time, and feed phase $\mathrm{pH}$ of 1 .

Table 2: Reaction rate constants for extraction $\left(\mathrm{k}_{1}\right)$ and stripping $\left(\mathrm{k}_{2}\right)$ reaction of $\mathrm{Cd}(\mathrm{II})$ ions through BLM.

\begin{tabular}{ll}
\hline Rate constants & Experimental data $\left(\mathrm{h}^{-1}\right)$ \\
\hline $\mathrm{k}_{1}$ & 0.940 \\
$\mathrm{k}_{2 \mathrm{~m}}$ & 2.589 \\
$\mathrm{k}_{2 \mathrm{p}}$ & 2.410 \\
$\mathrm{k}_{2}$ (average value) & 2.450 \\
\hline
\end{tabular}

The predicted model line was plotted by using $\mathrm{k}_{1}$ and $\mathrm{k}_{2}$ (average value) as tabulated in Table 2. The value of $k_{1}$ was directly obtained by iteration from Equation 6 until it introduced a constant value. An initial value of $k_{2}$ was later identified. $k_{2 m}$ and $k_{2 p}$ were known via fittings of Equations 7 and 8 . The average value of $\mathrm{k}_{2}$ was calculated by taking the mean of the reaction rate constants for reactions that occurred to extract and strip the $\mathrm{Cd}(\mathrm{II})$ ions. From the plot, the experimental data were found to be well fitted with the models shown in Equations 6, 7 and 8, where the $\mathrm{R}^{2}$ values were found to be $0.986,0.972$ and 0.985 for data of $R_{f}, R_{m}$ and $R_{p}$, respectively. It is highly possible due to the fact that TOA is a highly efficient carrier and in this study at $0.1 \mathrm{wt} \%{ }^{24}$ This mechanism has been used to describe the transport of ions through BLM which Cd(II) ions transport obeys the kinetic laws. ${ }^{23}$ 


\section{CONCLUSION}

An extraction system for $\mathrm{Cd}(\mathrm{II})$ ions through BLM system containing TOA as carrier was studied. The study suggested that the extraction of $\mathrm{Cd}(\mathrm{II})$ ions across BLM prefers acidic condition at $\mathrm{pH}$ of 1 . The results also prove that the capability of $\mathrm{Cd}(\mathrm{II})$ ions extraction in BLM system is strongly influenced by the carrier concentration, stirring speed and also extraction time. The highest removal efficiency of $\mathrm{Cd}(\mathrm{II})$ was obtained by using $0.1 \mathrm{wt} \%$ of TOA concentration at stirring speed of $400 \mathrm{rpm}$. As for the extraction time, a comparative kinetic study of the Cd(II) transport through BLM were analysed by means of a kinetic model and the rate constants of the reactions were determined by numerical analysis of experimental results with $\mathrm{k}_{1}$ value of $0.94 \mathrm{~h}^{-1}$, and average value of $\mathrm{k}_{2}$ is $2.450 \mathrm{~h}^{-1}$. The model and experimental data were observed to have good agreement, hence revealing that TOA is capable to extract $\mathrm{Cd}(\mathrm{II})$ ions form an aqueous solution.

\section{ACKNOWLEDGEMENTS}

Financial support by the Fundamental Research Grant Scheme (FRGS/2017/ TK02/UITM/03/11) from Ministry of Higher Education Malaysia and facilities provided by Universiti Teknologi MARA, Malaysia are greatly acknowledged and appreciated.

\section{REFERENCES}

1. Chen, P. et al. (2016). Systematic network assessment of the carcinogenic activities of cadmium. Toxicol. Appl. Pharmacol., 310,150-158, https://doi.org/10.1016/j. taap.2016.09.006.

2. Wu, G.-X. et al. (2006). Accumulation of cadmium and its effects on growth, development and hemolymph biochemical compositions in Boettcherisca peregrina larvae (Diptera: Sarcophagidae). Insect Sci., 13(1),31-39, https://doi. org/10.1111/j.1744-7917.2006.00065.x.

3. Černá, M. (1995). Use of solvent extraction for the removal of heavy metals from liquid wastes. Environ. Monit. Assess., 34(2),151-162, https://doi.org/10.1007/ BF00546029.

4. Ahmed, S., Chughtai, S. \& Keane, M. A. (1998). The removal of cadmium and lead from aqueous solution by ion exchange with Na-Y zeolite. Sep. Purif. Technol., 13(1), 57-64, https://doi.org/10.1016/S1383-5866(97)00063-4.

5. Mahmood, M. et al. (2011). Removal of heavy metals using chemicals precipitation. Eng. Tech. J., 29(3), 595-612.

6. Kislik, V. S. (2015). Liquid membrane separation. In (Eds.) Drioli, E. \& Giorno, L. Encyclopedia of membranes. Berlin: Springer Berlin Heidelberg, 1-3. 
7. Ahmad, A. L. et al. (2011). Emulsion liquid membrane for heavy metal removal: An overview on emulsion stabilization and destabilization. Chem. Eng. J., 171(3), 870-882, https://doi.org/10.1016/j.cej.2011.05.102.

8. Muthuraman, G. \& Teng, T. T. (2009). Use of vegetable oil in supported liquid membrane for the transport of Rhodamine B. Desalin., 249(3), 1062-1066, https:// doi.org/10.1016/j.desal.2009.05.017.

9. Chang, S. H. (2014). Vegetable oil as organic solvent for wastewater treatment in liquid membrane processes. Desalin. Water Treat., 52(1-3), 88-101, https://doi.or $\mathrm{g} / 10.1080 / 19443994.2013 .782829$.

10. Malik, M. A., Hashim, M. A. \& Nabi, F. (2011). Ionic liquids in supported liquid membrane technology. Chem. Eng. J., 171(1), 242-254, https://doi.org/10.1016/j. cej.2011.03.041.

11. Mateescu, M. et al. (2013). Transport of cadmium ions through a bulk liquid membrane with D2EHPA as carrier. Sci. Bull. B, 75(2), 67-74. https://www. scientificbulletin.upb.ro/rev_docs_arhiva/full87f_400567.pdf.

12. Marino, T. \& Figoli, A. (2015). Arsenic removal by liquid membranes. Membr., 5(2), 150-167, https://doi.org/10.3390/membranes5020150.

13. Kumbasar, R. A. (2009). Extraction and concentration study of cadmium from zinc plant leach solutions by emulsion liquid membrane using trioctylamine as extractant. Hydrometal. 95(3), 290-296, https://doi.org/10.1016/j.hydromet.2008.07.001.

14. Hajarabeevi, N. et al. (2009). Facilitated transport of cationic dyes through a supported liquid membrane with D2EHPA as carrier. Desalin., 245(1), 19-27, https://doi.org/10.1016/j.desal.2008.06.009.

15. Swain, B. et al. (2007). Separation of Co(II) and Li(I) by supported liquid membrane using Cyanex 272 as mobile carrier. J. Membr. Sci., 297(1), 253-261, https://doi. org/10.1016/j.memsci.2007.03.051.

16. Yang, X. J. \& Fane, A. G. (1999). Performance and stability of supported liquid membranes using LIX 984N for copper transport. J. Membr. Sci., 156(2), 251-263, https://doi.org/10.1016/S0376-7388(98)00351-2.

17. León, L. et al. (2016). Kinetic study of copper(II) simultaneous extraction/stripping from aqueous solutions by bulk liquid membranes using coupled transport mechanisms. Metals, 6(9), 212 https://doi.org/10.3390/met6090212.

18. Leon, G. \& Guzmán, M. A. (2008). Facilitated transport of copper through bulk liquid membranes containing different carriers: Compared kinetic study. Desalin., 223(1-3), 330-336, https://doi.org/10.1016/j.desal.2007.01.216.

19. Basualto, C. et al. (2006). Extraction of cadmium from aqueous solutions by emulsion liquid membranes using a stirred transfer cell contactor. J. Braz. Chem. Soc., 17(7), 1347-1354, https://doi.org/10.1590/S0103-50532006000700023.

20. Burmester, S. S. H., Rielly, C. D. \& Edwards, M. F. (1992). The mixing of miscible liquids with large differences in density and viscosity. In (Eds.) King, R. Fluid mechanics of mixing: Modelling, operations and experimental techniques. Dordrecht: Springer, 83-90.

21. Ahmad, A. L. et al. (2017). Utilization of environmentally benign emulsion liquid membrane (ELM) for cadmium extraction from aqueous solution. J. Water Process Eng., 15, 26-30, https://doi.org/10.1016/j.jwpe.2016.05.010. 
22. Franzreb, M. et al. (2001). Liquid-phase mass transfer of magnetic ion exchangers in magnetically influenced fluidized beds: II. AC fields. React. Funct. Polym., 46(3), 247-257, https://doi.org/10.1016/j.reactfunctpolym.2004.02.007.

23. Chang, S. H., Teng, T. T. \& Norli, I. (2011). Cu(II) transport through soybean oil-based bulk liquid membrane: Kinetic study. Chem. Eng. J., 173(2), 352-360, https://doi.org/10.1016/j.cej.2011.07.062.

24. Chakrabarty, K. et al. (2009). Extraction and recovery of lignosulfonate from its aqueous solution using bulk liquid membrane. J. Membr. Sci., 330(1), 135-144, https://doi.org/10.1016/j.memsci.2008.12.069. 